JEL: P45, Q02, Q17

\author{
Hassan Ali Al-Ababneh ${ }^{1}$,Ainur Osmonova ${ }^{2}$, Ilona Dumanska ${ }^{3}$, \\ Petro Matkovskyi, Andriy Kalynovskyy ${ }^{5}$ \\ ${ }^{1}$ Irbid National University \\ ${ }^{2}$ Kyrgyz-Russian Slavic University named after B. N. Yeltsin \\ ${ }^{3}$ Khmelnytskyi National University \\ ${ }^{4}$ Vasyl Stefanyk Precarpathian National University \\ ${ }^{5}$ Lviv Polytechnic National University \\ ${ }^{1}$ Jordan \\ ${ }^{2}$ Kyrgyz Republic \\ ${ }^{3,4,5}$ Ukraine
}

\title{
ANALYSIS OF EXPORT OF AGRICULTURAL PRODUCTS IN THE CONTEXT OF THE GLOBAL FOOD CRISIS
}

Purpose. The purpose of this article is to study the nature, main trends and problematic aspects of realization of the export potential of agricultural production in the countries of South America, OECD, North America and Europe in the context of aggravating food crisis.

Methodology / approach. Theoretical and empirical methods of cognition are used in their dialectical combination. The main methods used in this study are statistical analysis, index, graphical and analytical methods, methods for estimating structural dynamic shifts, comparisons and monographic method. The study also involved general methods of economic research, in particular: theoretical generalization and comparison, induction and deduction are used in revealing the content of the export potential of agricultural production, drawing conclusions; the current condition and tendencies of development of export of agricultural products is estimated by means of synthesis and the economic analysis; graphic, economic, statistical and interstate comparisons are used to analyse the export of agricultural products; statistical methods (grouping) are applied to assess the domestic and external export potential of agricultural products in the regional context. The influence of external and domestic export potential on wheat exports is studied by regression analysis.

Results. The need to ensure food security by countries around the world urges the importance of the agricultural sector as a catalyst for economic development, sources of foreign exchange earnings, investment direction, etc. The study of agricultural specialization led to the conclusion that wheat and sugar are goods with the highest export potential. It is substantiated that the countries of South America, OECD, North America and Europe have the highest level of fulfilment of export potential of agricultural production, and African countries are import-dependent. Besides, the low export orientation of Africa and Asia due to the peculiarities of their natural and climatic conditions is established based on the assessment of export-import operations in the regional context. The internal and external export potential of each of the regions is analysed. The direct correlation between the exports volume and area of land used for wheat cultivation, as well as with its yield, was established through the correlation and regression analysis.

Originality / scientific novelty. The scientific novelty of the results of the study is that the authors were the first who carried out a comprehensive analysis of the potential capacity and ability to increase exports of agricultural products in the world and by product groups. The essence and features of economic representation of export potential of agricultural products at the international and national levels are determined. The main factors influencing the development of the export 


\section{Agricultural and Resource Economics: International Scientific E-Journal}

http://are-journal.com

potential of agricultural products in the regional context are outlined and their influence is investigated by carrying out the regression analysis. The study of domestic and foreign export potential by regions of the world is further developed.

Practical value / implications. The analysis of the internal and external export potential of agricultural production was carried out in the regional context, which resulted in the identification of the main recommendations for increasing their level in order to enhance the development of the agro-industrial sector of the economy.

Key words: export potential, agricultural production, export, integration, food security.

Introduction and review of literature. One of the most difficult challenges today is to prevent the food crisis. According to UN experts, it is the worst in the last 50 years of human development and requires an immediate response from governments to avoid a catastrophe. It should be noted that food security problems directly depend on the development of the agro-industrial sector, which is currently the basis for increasing its export potential, a factor in ensuring national food security and meeting public demand for major groups of agricultural products.

The food crisis is most often associated with the rapid growth of the world population and the irrational use of natural resources, the decline in the level of ecologisation of economic development. Most countries focus on investing in profitable and fast-paying sectors of the economy, while the agricultural sector was financed mostly on a residual basis. Besides, there has been a tendency to reduce the area under crops suitable for growing food crops in recent years, while the cultivation of industrial crops used for biofuel production has become increasingly popular. All this contributed to the growth of the deficit of agricultural products and, as a consequence, to the increasing price for them. Thus, according to FAO (2017), prices have almost doubled in the last decade, making these groups of goods less accessible to low-income people.

In the context of the Covid-19 pandemic, the situation in this area worsened significantly, therefore it is correct to assume that there will be a decline in food security in the world over the next few years, accompanied by disruptions in food supply chains even in economically developed countries. In addition, the spread of the pandemic and the introduction of significant quarantine restrictions have led to significant labor shortages in agriculture in different countries, which affected the yield, quantity and quality of harvested crops. The pandemic has also significantly affected the development of animal husbandry, restricting free access to feed and veterinary drugs.

It should be noted that since the beginning of the pandemic most countries have resorted to significant export restrictions in order to provide food for their domestic markets, which also significantly affected the international market and provoked supply disruptions and rising prices for agricultural products.

However, rethinking the strategic importance of each of the economic sectors of development and understanding the realities of today, an increasing number of countries urge the need to develop and promote the agro-industrial complex. In the context of such changes, appropriate agricultural programs, systems of financial 


\section{Agricultural and Resource Economics: International Scientific E-Journal}

http://are-journal.com

incentives and support for farmers are being developed, which significantly affects the level of supply of agricultural products within individual countries. It is under such conditions that issues related to the development and effective use of the export potential of agricultural production become especially relevant.

Today, it is one of the independent elements of the country export potential, which is able to increase the competitiveness of countries that have such potential and are able to use it effectively. Besides, there is a shift in economic emphasis in favour of stimulating the development of countries that have significant prerequisites for agricultural development, as well as developed logistics and marketing systems that allow creating reliable and uninterrupted food supply chains.

Thus, a rational approach to the use of the export potential of agricultural production will create the preconditions not only to overcome the negative effects of the food crisis, but also to equalize food security at the international level, and will balance foreign economic activity in this area.

The efficiency of export potential largely determines the financial stability of the state. In turn, this problem is especially important for agricultural producers, as modern globalization processes of the world economy have intensified competition in both foreign and domestic markets. European exports are the main form of realization of the export potential. This means that Ukrainian exporters of agricultural products focus on EU quality standards, as the EU market is the main market for Ukrainian agricultural products. The Free Trade Agreement between Ukraine and the EU has institutionalized preferential terms of trade, but European quality standards are mandatory for those companies that export products to EU countries. At the same time, compliance with European product quality standards significantly improves the export potential of Ukrainian agricultural companies.

Actually, the export potential of an agricultural producer characterizes the part of the production potential that can be directed to the creation of products to be sold in foreign markets. Lavriv (2016) proposed a classification and arranged a single system of factors influencing the export potential of agricultural companies. In particular, singling out integration as a separate group of factors is important for the fulfilment of their export potential. Huai et al. (2020) identified the country's reputation as an important factor influencing export quality. The results of their research showed that the country's reputation has a positive and significant impact on the quality of exports. Based on research, it is substantiated that the rapid increase in population in general slows down agricultural production and exports of the country (Hoffmann, 2011). In developing countries, population growth rates are almost twice as high as in developed countries, which creates difficulties for agricultural production in these countries due to damage to the physical environment caused by population growth, and limits agricultural production opportunities for farmers (FAO, 2017). Food security and supply is one of the global problems of mankind. In their article, Turobova and Kodirov (2016) highlighted the importance of farms in agriculture and their role in agricultural exports.

Foreign trade in agricultural and food products is a significant reflection of the 
economic situation observed in the current functioning of agriculture, food industry and certain types of trade in a particular country (Firlej \& Kubala, 2018). So, assessing the export potential of agricultural and food products in the Visegrad countries in 2005-2017, researchers proved that exports of agricultural and food products to the Visegrad countries are vulnerable to economic trends, there is a significant degree of competitiveness in exporting food products of animal origin to these countries, as well as the highest level of competitiveness of foreign trade in food products of plant origin in relation to cereals, while trade in fruits and vegetables is becoming less important.

In response to rising world prices for agricultural and food products, many countries have introduced controls on their agricultural exports, using taxes, quotas and total export bans. Besides, many countries have maintained export taxes not only on agricultural goods but also on forestry and fishery products, minerals, metals and precious stones over the past few decades (Liefert \& Westcott, 2015).

Studying the export of agricultural and food products in Georgia, Maximov and Saha (2017) found that it is concentrated in a few goods and a few unpretentious markets, which makes it extremely vulnerable to a small number of commodity and geographic markets. At the same time, the diversity of climatic conditions and large water resources create a significant potential for growth and diversification of Georgian agriculture. Today, two main restrictions limit the export of agricultural and food products of Georgia: 1) the shortage of raw materials due to low agricultural productivity limits the number of goods available for export; 2) most export chains are poorly organized. Therefore, the government should encourage and support the establishment of agricultural clusters in the short term, potentially in the context of a broader initiative of agricultural and industrial clusters.

A study conducted by Khan et al. (2020) revealed short-term and long-term factors affecting Pakistan's agricultural exports as an agriculture-based country (the agricultural sector is the backbone of the national economy). Given the national economy and the agricultural sector, it is necessary to focus on the export of agricultural products to improve the life of local farmers.

Osabohien et al. (2019) explored the potential of agricultural exports in Nigeria, which realizes it by exporting both traditional goods such as cocoa, rubber, palm products, cotton, hides, crafts and textiles, and non-traditional ones. The Federal Government of Nigeria prioritizes agricultural development through its Economic Recovery and Growth Plan, which seeks to create new jobs in labour-intensive sectors, including agriculture, and turns the country into a powerful exporter of major crops, including rice, cashews, peanuts, vegetable oil and cassava. The government seeks to promote sustainable growth in both crop production and agricultural exports through a number of policies, including the development of key crop processing areas and reform of the quality control process. There are also huge opportunities for the development of non-traditional exports of products such as medicinal plants, snails, mushrooms, cultivated wildlife and more. It is reasonable to use the practice of other developing countries that the growth of agricultural exports should be based on turning mediumsized and large commercial companies into efficient small farms. 


\section{Agricultural and Resource Economics: International Scientific E-Journal}

http://are-journal.com

Agriculture also plays a crucial role in Iran's economy in terms of food security, job creation and foreign income. Using data on 38 destination countries from 1982 to 2017, Shokrollah et al. (2020) found a direct and significant impact of GDP and population of trading partners on Iran's agricultural exports, while distance and border barriers imposed by destination countries show significant reverse effect. Measures to promote competitiveness are recommended, along with free bilateral and regional trade agreements to remove border barriers.

The article of Pang and Wang (2019) covers the situation with Chinese agricultural exports from 2007 to 2016 and the problems of Chinese agricultural exports, as well as analyses the international multilateral system of environmental and ecolabelling of Chinese agricultural exports and the impact of these environmental regulations on exports. The authors conclude that international environmental regulation has a significant negative impact on Chinese agricultural exports.

Ferro et al. (2015) introduced a standard cap index to study the impact of food safety standards on international agricultural exports. This standard limitation indicator is based on the use of maximum pesticide residue levels for 61 importing countries and 66 different products. The index takes into account both the amount of pesticides regulated for each product and the permissible level of these pesticides by each importer. The data obtained indicate that compliance with strict standards increases the fixed costs of exports to the destination.

An analysis of the Baltic countries by Remeikiene et al. (2018) showed that the realization of export potential also depends on the characteristics of agriculture and subsidies from EU funds, which are relatively low compared to the old EU member states. Besides, support for agriculture creates relatively unequal conditions of competition for other economic activities. As a result, it is doubtful whether the export of agricultural products contributes to the prosperity of the Baltic economy. A correlation and regression analysis was used covering data from 2000-2016 to achieve this goal - studying the links between agricultural exports and economic growth in the Baltic States. Empirical calculations have shown that the export of agricultural products (in some sections) contributes very little to the growth of GDP in the Baltic economies; however, this negatively affects labour market indicators (selfemployment, employment in the land sector, the level of the labour market).

Fulfilling the export potential of agricultural producers is also influenced by integration processes. This conclusion is confirmed by researchers Richardson et al. (2020), who estimated the potential effects of free trade areas and common currency based on data from 45 African countries for 1996 to 2018. Accession to the Arab Maghreb Union (AMU), the Community of Sahel-Saharan (CS-SS), the Common Market for East and South Africa (COMESA), the East African Community (EAC), the Economic Community of Central African States, the Intergovernmental Authority on Development (IGAD), the Economic Community of West African States (ECOWAS), the South African Development Community (SADC) or membership in the African Continental Free Trade Area (AFCFTA) have boosted agricultural exports. Anania (2013) emphasizes the obligation to restrict exports both within and 
outside the WTO. Gilbert (2012) discusses why international commodity agreements are not an effective option to address food security issues on a multilateral basis, including the introduction of stricter rules on export restrictions. In principle, it is the activities of major grain countries, importers and exporters that have the greatest impact on international markets related to food security, which means that a voluntary binding agreement between a small group of largest producers, exporters and importers may be sufficient to obtain desired outcome (Headey \& Fan, 2010).

Sidorskiy (2014) studied the impact of the creation of the Common Economic Space in the Eurasian Economic Union on the creation of an effective competitive environment and ensuring the proper functioning of the common agricultural market.

Several researchers have studied the impact of economic integration on agricultural performance with different outcomes. Some studies revealed positive effects, while others found negative ones. However, some studies confirm a slight relationship between economic integration and agricultural performance. In particular, assessing the impact of the free trade area on the promotion of intra-regional trade, Elbushra et al. (2011) confirm that free trade areas promote the export of agricultural products. Olayiwola et al. (2015) confirm that regional integration and trade blocs stimulate exports. Other studies by Shobande (2019) indicate that economic integration is a strong driver of export efficiency, while an effective nominal exchange rate slows down agricultural exports. Other studies that report a negative correlation between exchange rates and agricultural exports include Rahman and Dutta (2012) in the case of Bangladesh, Narayan and Nguyen (2016) in the case of Vietnam.

Ukrainian scientists have made a significant contribution to the study of the export potential of agricultural products. Hranovska (2018) studied the structure of Ukrainian exports of agricultural products and identified the main favourable factors for the development of Ukrainian logistics. However, the issue of the reasons for the export potential of Ukrainian agricultural products, which is determined not only by fertile soils, has not been considered.

In the study of the export potential of agricultural companies, the authors (Saikevych \& Saikevych, 2013) conclude that the formation of export potential is a difficult task. One of the main criteria of export potential is product quality standards, compliance with which ensures competitiveness in the international market. The difficulty of estimating the export potential due to the export volumes of agricultural products is due to the fact that the vast majority of products go abroad through intermediaries, rather than directly to agricultural companies.

Rossokha and Sharapa (2016), having studied the volumes and sales channels of agricultural companies, came to the conclusion that increasing the export potential of agricultural products is possible through their processing. WTO membership has opened new markets for Ukrainian companies, so it is necessary to export products with high added value. This is possible only through the formation of added value within the Ukrainian economy.

In the study of the export potential of agricultural products, Nakonechna (2019) concludes that the export potential should be improved through certification. This will 
increase exports to the EU, where there is a strict certification system. Besides, export potential development programmes need to be developed and implemented, which should be supported by free trade agreements. Gansa (2015) considers the export potential of Ukrainian companies in the agro-industrial complex in the context of European integration. The author notes that the advantages of Ukrainian exporters include a wide range of products and high quality. However, further development of export potential requires updating the material and technical resources, and introducing modern technologies in companies. This will ensure the competitiveness of Ukrainian agricultural products in a highly competitive EU market.

So, the issue of fulfilling the export potential of agricultural producers of different countries is widely represented in scientific publications, but the outlined topic requires current research on the development of agricultural exports. The analysed studies of both Ukrainian and foreign scientists do not reveal the issue of assessing the use of the export potential of agricultural products, which becomes especially relevant in the context of the intensification of the global food crisis. Our research is aimed at solving this issue.

The purpose of the article. The purpose of this article is to study the nature, main trends and problematic aspects of realization of the export potential of agricultural production in the countries of South America, OECD, North America and Europe in the context of aggravating food crisis.

To achieve the goal, the following tasks were solved: to determine the essence and features of the export potential of agricultural products at the international and national levels; to analyse the dynamics of consumption of the main groups of agricultural products in the world; to identify current trends in realization of the export potential of agricultural products in the regional context; to identify the factors affecting the export potential, and assess the level of their influence on the volume of agricultural exports.

Methods. Fig. 1 shows a generalized research design. Given that the problem of realization of the export potential of the agricultural sector is global, OECD countries, North America, Europe, Africa, South America and Asia are selected as the object of study. This approach will allow a comprehensive study of the outlined issues. The main indicators used for the analysis are: imports, exports and foreign trade balance by major groups of agricultural products characterized by the highest level of consumption in the international market.

The main methods used in this study are the following: statistical analysis was used to assess the dynamics of exports for the analysed period; graphical and analytical methods in combination with comparisons and monographic method were used to present data in graphical form and to estimate structural dynamic shifts. The study also involved common methods of economic research, in particular: theoretical generalization and comparison, induction and deduction (when revealing the content of the export potential of agricultural production, drawing conclusions); synthesis and economic analysis (to assess the current state and development trends of agricultural exports); graphical, economic-statistical and interstate comparisons (for the analysis of 


\section{Agricultural and Resource Economics: International Scientific E-Journal http://are-journal.com}

agricultural exports); statistical groupings (to assess the domestic and external export potential of agricultural products in the regional context); economic-and-mathematical simulation (regression analysis) (to determine the impact of factors on wheat exports), etc.

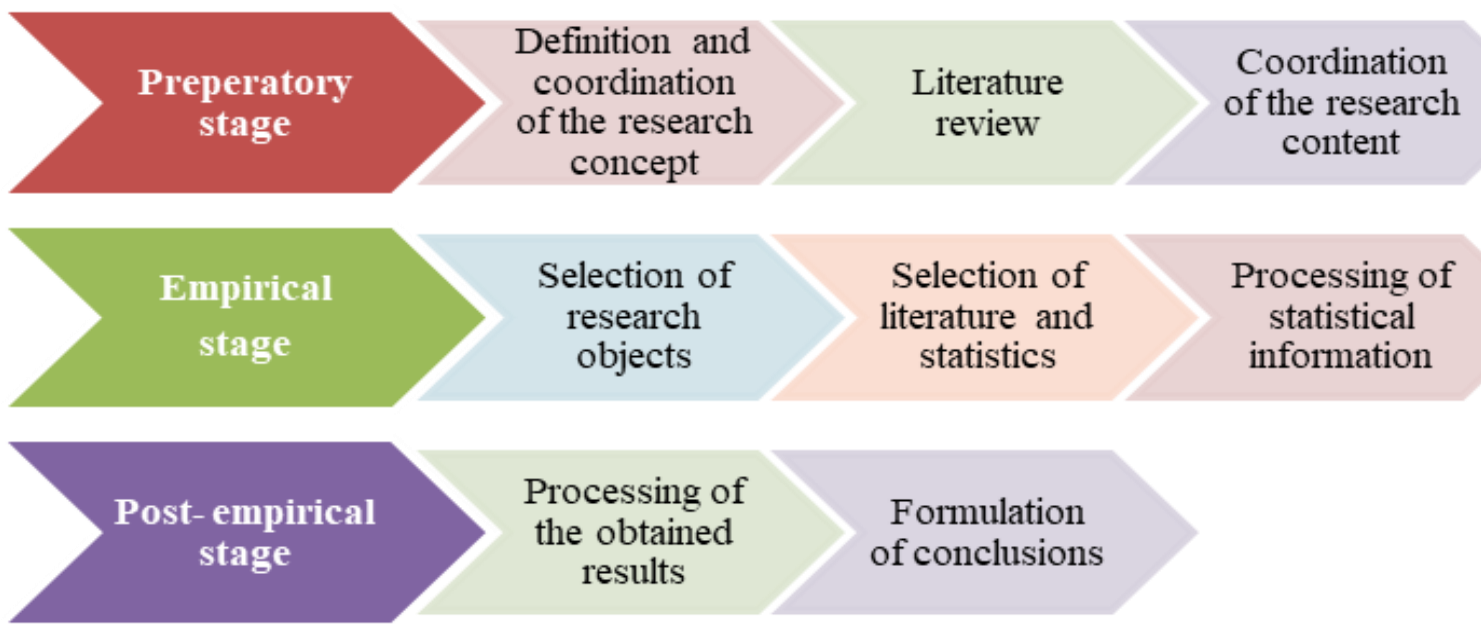

Source: built by the authors.

For the statistical analysis, we used the program "Statistica", which allowed determining the influence of factors on the resultant value and to building the corresponding linear regression equation.

Results and discussion. The export potential is interpreted from different aspects in the scientific literature. In particular, Hranovska (2018) understands the export potential as the volume of exports in terms of product structure, which follows from her analysis of export potential. Saikevych and Saikevych (2013) also understand the export potential as the volume of exports and indicators of trade conditions, taking into account export income. Firlej and Kubala (2018) understand the export potential as the competitive advantages of the country in the production of certain types of agricultural products. Khan et al. (2020) view export potential as an opportunity to increase agricultural production and exports in response to growing aggregate demand for it in domestic or international markets.

Given these approaches to the interpretation and understanding of export potential, we will use the authors' interpretation of export potential for the purposes of our study. The authors' understanding of the export potential of agricultural products includes export potential at the national and international levels. Export potential is determined at the international level by significant competitive advantages for exporters and their ability to effectively use existing market opportunities. In numerical terms, it will be represented by the share of export products in the international market. At the national level, this category should be considered as a set of opportunities and resources to increase agricultural production in order to carry out export operations, and will be expressed by the value of the foreign trade balance in the study area.

Fulfilment of the national export potential can become a solid background for the development of other sectors of the economy due to its diversification capacity. At the international level, export potential is one of the powerful tools for equalizing food 
security between countries.

The main factors influencing the export potential of agricultural production are the following:

- geographical location of the country, its natural and climatic conditions;

- social traditions of agricultural development;

- availability of skilled labourers for employment in agricultural production;

- financial opportunities for the development of agricultural production;

- effective regulatory framework in the field of export operations;

- opportunities for diversification of agricultural production into other sectors of the economy;

- credit support for the development of export potential of agricultural producers;

- availability of standards for agricultural production and quality assurance of such groups of goods;

- the ability of exporters to respond flexibly to changes in agricultural market conditions.

Examining the export potential of agricultural production, it is necessary to analyse the consumption of the main groups of agricultural products per capita (Fig. 2), which will determine the priority of their exports.

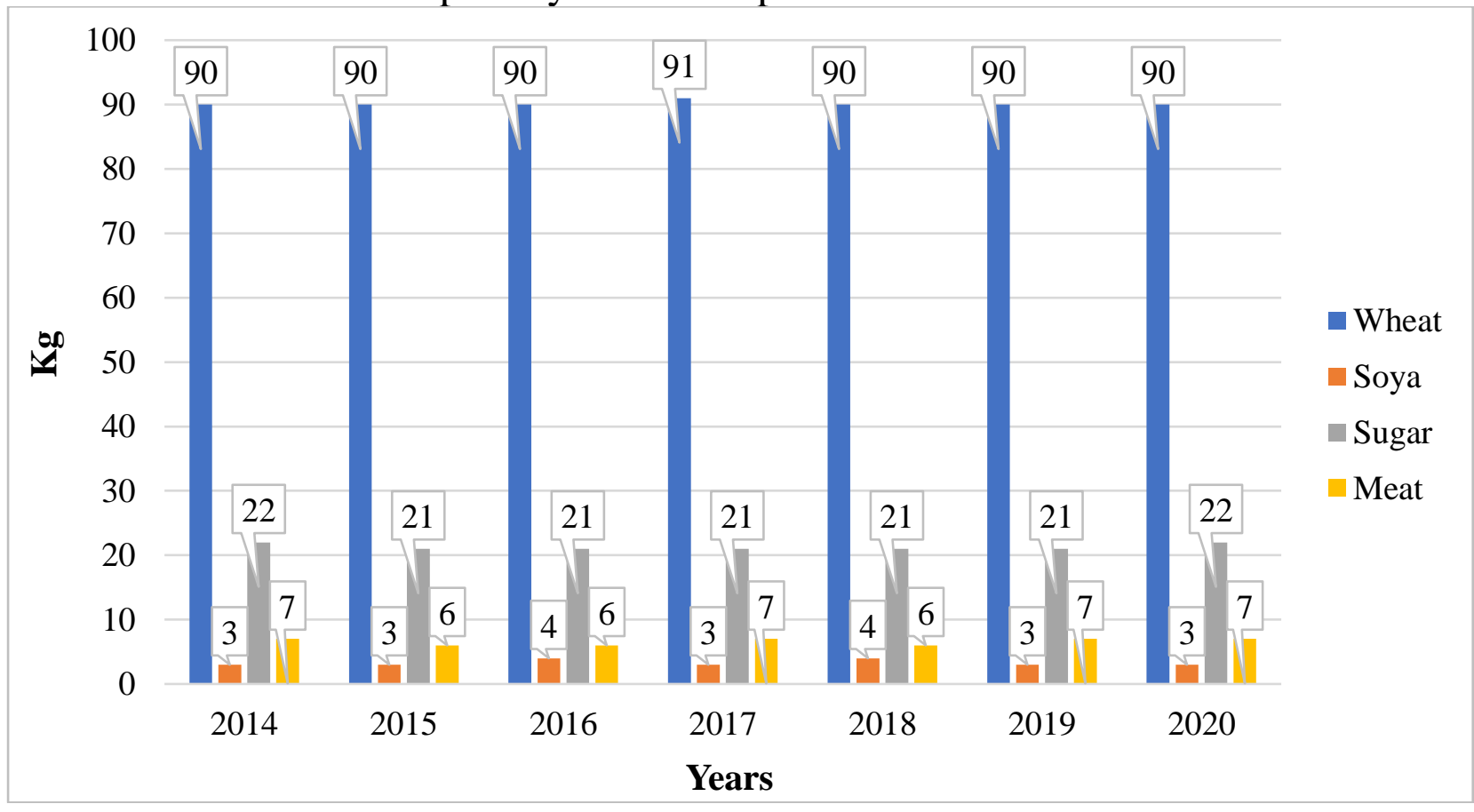

Fig. 2. Volumes of consumption of agricultural products per capita in OECD countries for 2014-2020, $\mathrm{kg}$

Source: calculated and built by the authors based on the OECD (2020).

According to OECD (2020) data, wheat, soybeans, meat and sugar have the largest volumes of consumption (Fig. 2) and exports (Fig. 3) of agricultural products in OECD countries in 2014-2020. Given the largest share of these products, our study of export potential will focus on these products.

According to Fig. 2, it can be concluded that the priorities of consumption are stable during 2014-2020, with wheat and sugar being in the greatest demand, and 
therefore these goods will have a higher export potential. The data of Fig. 2 show that wheat, soybeans, sugar and meat were consumed at a steady pace during the analysed period, which indicates the importance and irreplaceability of these products in the world market of agricultural products. Given the steady rate of consumption of these products, we can say that these goods are also in steady demand in the international market, regardless of the state of national economies and global economic trends.

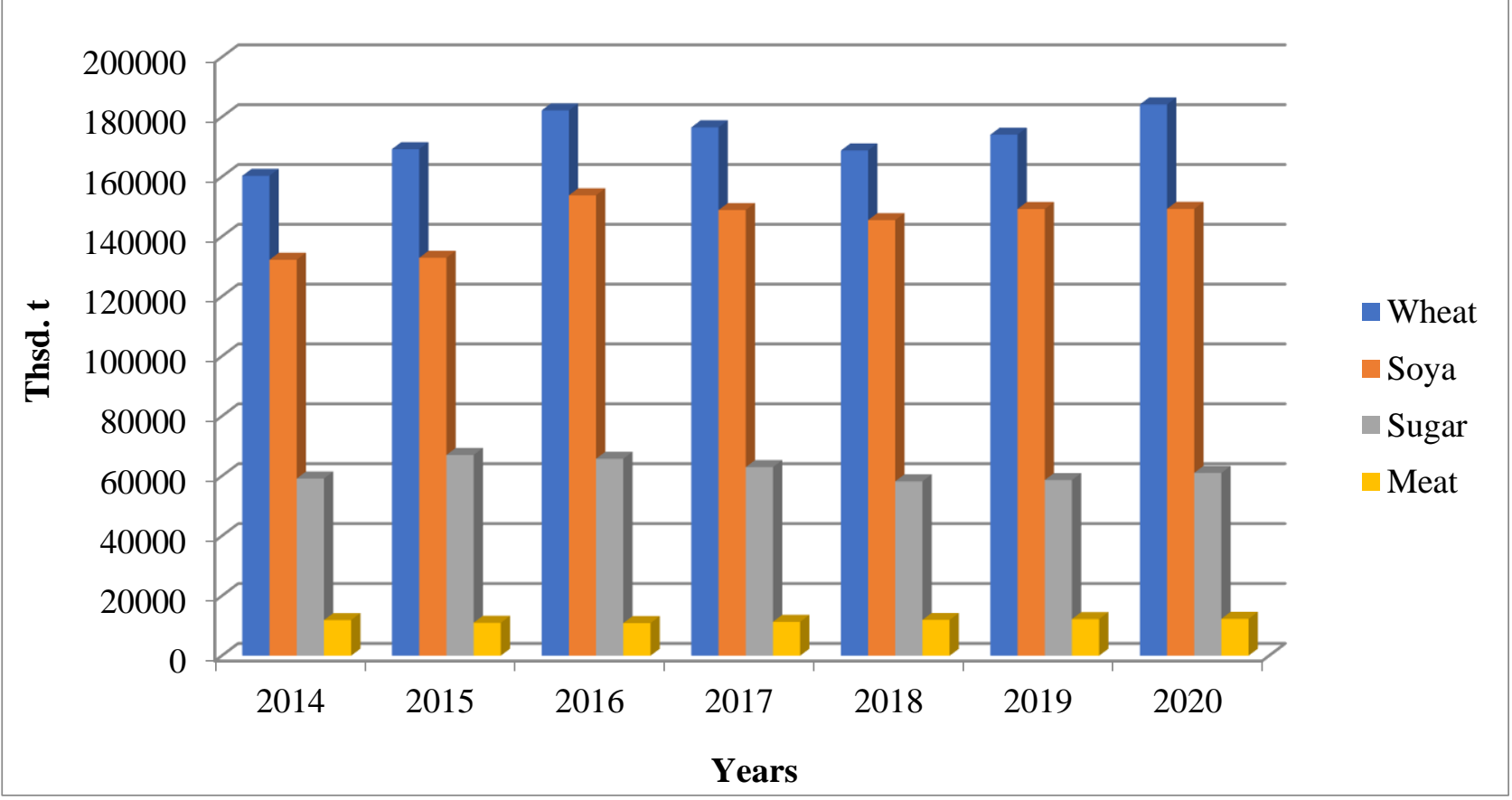

Fig. 3. Export volumes of export-oriented groups of goods in OECD countries for 2014-2020, thsd. $t$

Source: calculated and built by the authors based on the OECD (2020).

This statement is supported by the data of Fig. 3, which illustrates the dynamics of exports of major groups of goods that were top in export operations during 20142020. It should be noted that the volume of exports of major product groups decreased slightly in 2017-2018, but increased in 2019-2020 and reached the level of 2016. Such dynamics of grain, soybean, sugar and meat exports indicate a consistently high demand for them on the world market, regardless of the crisis caused by financial factors or the COVID-19 pandemic. The structure of exports during the study period remains actually unchanged.

In order to study the export potential in detail, we will analyse the exports volume of the main groups of agricultural products in the regional context, namely in the OECD countries, North America, Europe, Africa, South America and Asia. In this case, the main indicators that will be used for analysis are: imports, exports and foreign trade balance by goods (Table 1). The export indicator characterizes the ability of OECD countries to produce and supply products to foreign markets. The import indicator describes the purchase of products abroad, as not all OECD countries can meet their domestic needs in all products through domestic production. The foreign trade balance shows the ratio of exports to imports of the four products. Thus, if exports dominate over imports, it means that the country has export potential in the product and realizes it. 


\section{Exports, imports of agricultural products in 2014-2020 in the regional context,} mln USD

\begin{tabular}{|c|c|c|c|c|c|c|c|c|}
\hline \multirow{17}{*}{$\begin{array}{l}\cdot \stackrel{\mathscr{U}}{\Xi} \\
\Xi \\
0 \\
0 \\
0 \\
0 \\
0\end{array}$} & \multirow{2}{*}{ Indicator } & 2014 & 2015 & 2016 & 2017 & 2018 & 2019 & 2020 \\
\hline & & \multicolumn{7}{|c|}{ Wheat } \\
\hline & Import & 38145.58 & 35846.23 & 36406.23 & 39272.56 & 38592.25 & 37998.35 & 38919.14 \\
\hline & Export & 104765.97 & 100705.85 & 108048.69 & 89902.18 & 87783.30 & 94436.12 & 99712.98 \\
\hline & Balance & 66620.39 & 64859.62 & 71642.46 & 50629.62 & 49191.05 & 56437.77 & 60793.84 \\
\hline & \multicolumn{8}{|c|}{ Soya } \\
\hline & Import & 26797.10 & 28784.60 & 28159.07 & 28176.65 & 31138.61 & 30151.54 & 30273.51 \\
\hline & Export & 52852.35 & 56169.84 & 62791.38 & 62474.28 & 52527.09 & 51975.69 & 52010.68 \\
\hline & Balance & 26055.25 & 27385.24 & 34632.31 & 34297.63 & 21388.48 & 21824.15 & 21737.17 \\
\hline & \multicolumn{8}{|c|}{ Sug } \\
\hline & Import & 13185.51 & 13288.77 & 11844.09 & 10987.47 & 11624.3 & 12091.84 & 11921.44 \\
\hline & Export & 9108.44 & 8757.3 & 8560.11 & 9711.14 & 9822.95 & 8436.13 & 8511.66 \\
\hline & Balance & -4077.07 & -4531.47 & -3283.98 & -1276.33 & -1801.35 & -3655.71 & -3409.78 \\
\hline & & & & & & & & \\
\hline & Import & 4493.93 & 4673.47 & 4718.14 & 4773.72 & 5245.52 & 5066.71 & 5003.62 \\
\hline & Export & 5975.12 & 5888.74 & 5724.8 & 5847.77 & 6239.38 & 6320.25 & 6112.99 \\
\hline & Balance & 1481.19 & 1215.27 & 1006.66 & 1074.05 & 993.86 & 1253.54 & 1109.37 \\
\hline \multirow{16}{*}{ 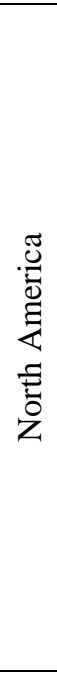 } & \multicolumn{8}{|c|}{ Wheat } \\
\hline & Import & 4197.82 & 3184.01 & 3321.09 & 4355.01 & 3793.06 & 2977.68 & 3429.94 \\
\hline & Export & 47471.42 & 42797.30 & 48759.52 & 46570.10 & 49903.04 & 50346.09 & 50013.91 \\
\hline & Balance & 43273.60 & 39613.29 & 45438.43 & 42215.09 & 46109.98 & 47368.41 & 46583.97 \\
\hline & \multicolumn{8}{|c|}{ Soya } \\
\hline & Import & 1229.33 & 972.18 & 1162.80 & 1214.30 & 1511.72 & 808.24 & 820.17 \\
\hline & Export & 52691.90 & 55838.34 & 62405.30 & 61998.13 & 52186.35 & 51578.32 & 51642.76 \\
\hline & Balance & 51462.57 & 54866.16 & 61242.50 & 60783.83 & 50674.63 & 50770.08 & 50822.59 \\
\hline & \multicolumn{8}{|c|}{ Sugar } \\
\hline & Import & 4369.00 & 4054.00 & 3429.00 & 3728.00 & 3650.00 & 4206.00 & 3972.60 \\
\hline & Export & 154.00 & 92.00 & 85.00 & 105.00 & 60.00 & 60.00 & 60.00 \\
\hline & Balance & -4215.00 & -3962.00 & -3344.00 & -3623.00 & -3590.00 & -4146.00 & -3912.60 \\
\hline & \multicolumn{8}{|c|}{ Meat } \\
\hline & Import & 2176.19 & 2268.28 & 2067.29 & 2034.50 & 2031.68 & 2066.13 & 2034.43 \\
\hline & Export & 1877.32 & 1652.75 & 1836.20 & 1969.89 & 2117.89 & 2243.99 & 2304.56 \\
\hline & Balance & -298.87 & -615.53 & -231.09 & -64.61 & 86.21 & 177.86 & 270.13 \\
\hline \multirow{16}{*}{ 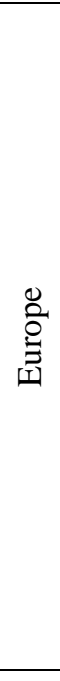 } & \multicolumn{8}{|c|}{ Wheat } \\
\hline & Import & 10461.06 & 12229.54 & 9791.84 & 10035.65 & 10655.56 & 9766.19 & 9819.32 \\
\hline & Export & 70370.40 & 80295.79 & 77415.75 & 84124.14 & 76683.65 & 82245.42 & 89282.05 \\
\hline & Balance & 59909.34 & 68066.25 & 67623.91 & 74088.49 & 66028.09 & 72479.23 & 79462.73 \\
\hline & \multicolumn{8}{|c|}{ Soya } \\
\hline & Import & 15972.55 & 17714.84 & 16648.45 & 16809.33 & 18447.28 & 18428.02 & 18358.16 \\
\hline & Export & 3008.68 & 3022.33 & 3731.86 & 3866.22 & 4310.51 & 3875.38 & 3886.05 \\
\hline & Balance & -12963.87 & -14692.51 & -12916.59 & -12943.11 & -14136.77 & -14552.64 & -14472.11 \\
\hline & \multicolumn{8}{|c|}{ Sugar } \\
\hline & Import & 5418.51 & 5566.77 & 4608.09 & 3186.47 & 3507.30 & 3520.84 & 3445.94 \\
\hline & Export & 2971.44 & 2995.30 & 4137.11 & 5786.14 & 3812.95 & 4475.13 & 3717.85 \\
\hline & Balance & -2447.07 & -2571.47 & -470.98 & 2599.67 & 305.65 & 954.29 & 271.91 \\
\hline & \multicolumn{8}{|c|}{ Meat } \\
\hline & Import & 1651.75 & 1440.66 & 1338.65 & 1337.87 & 1407.82 & 1351.99 & 1331.07 \\
\hline & Export & 1009.21 & 1102.42 & 1257.65 & 1305.53 & 1310.86 & 1245.31 & 1239.50 \\
\hline & Balance & -642.54 & -338.24 & -81.00 & -32.34 & -96.96 & -106.68 & -91.57 \\
\hline \multirow{4}{*}{$\stackrel{\Xi}{\circlearrowright}$} & \multicolumn{8}{|c|}{ Wheat } \\
\hline & Import & 47411.72 & 48086.98 & 47888.51 & 48081.17 & 46708.27 & 47924.77 & 52086.81 \\
\hline & Export & 1510.92 & 1069.97 & 979.96 & 1034.96 & 1024.45 & 1037.95 & 1016.61 \\
\hline & Balance & -45900.80 & -47017.01 & -46908.55 & -47046.21 & -45683.82 & -46886.82 & -51070.20 \\
\hline
\end{tabular}


Agricultural and Resource Economics: International Scientific E-Journal http://are-journal.com

\begin{tabular}{|c|c|c|c|c|c|c|c|c|}
\hline & \multicolumn{8}{|c|}{ Continuation of the Table 1} \\
\hline & \multicolumn{8}{|c|}{ Soya } \\
\hline & Import & 2921.78 & 2290.78 & 3419.78 & 4031.50 & 4675.50 & 5345.50 & 5882.33 \\
\hline & Export & 142.48 & 95.48 & 100.48 & 202.48 & 209.48 & 179.48 & 176.81 \\
\hline & Balance & -2779.30 & -2195.30 & -3319.30 & -3829.02 & -4466.02 & -5166.02 & -5705.52 \\
\hline & \multicolumn{8}{|c|}{ Sugar } \\
\hline & Import & 14241.08 & 13501.66 & 16708.99 & 15352.59 & 13906.44 & 13591.55 & 14284.75 \\
\hline & Export & 4722.20 & 4344.14 & 4692.28 & 4656.03 & 3892.06 & 3793.07 & 3937.10 \\
\hline & Balance & -9518.88 & -9157.52 & -12016.71 & -10696.56 & -10014.38 & -9798.48 & -10347.65 \\
\hline & \multicolumn{8}{|c|}{ Meat } \\
\hline & Import & 1242.47 & 1231.45 & 1006.30 & 908.89 & 835.16 & 852.53 & 852.13 \\
\hline & Export & 430.40 & 345.05 & 351.62 & 305.02 & 397.21 & 270.15 & 274.96 \\
\hline & Balance & -812.07 & -886.40 & -654.68 & -603.87 & -437.95 & -582.38 & -577.17 \\
\hline \multirow{16}{*}{ 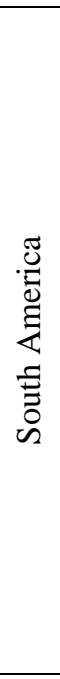 } & \multicolumn{8}{|c|}{ Wheat } \\
\hline & Import & 22163.04 & 22084.99 & 23908.01 & 24107.90 & 24579.90 & 24800.85 & 25318.74 \\
\hline & Export & 9181.12 & 12712.59 & 16619.92 & 13580.92 & 15378.85 & 16943.16 & 16901.43 \\
\hline & Balance & -12981.92 & -9372.40 & -7288.09 & -10526.98 & -9201.05 & 57.69 & -8417.31 \\
\hline & \multicolumn{8}{|c|}{ Soya } \\
\hline & Import & 6629.42 & 6708.37 & 7657.88 & 8800.34 & 14593.95 & 11118.29 & 8790.22 \\
\hline & Export & 75652.83 & 73449.68 & 86899.13 & 82159.19 & 88279.20 & 93137.14 & 93076.99 \\
\hline & Balance & 69023.41 & 66741.31 & 79241.25 & 73358.85 & 73685.25 & 82018.85 & 84286.77 \\
\hline & \multicolumn{8}{|c|}{ Sugar } \\
\hline & Import & 2249.17 & 2296.35 & 2290.53 & 2300.73 & 1819.93 & 1862.14 & 1887.55 \\
\hline & Export & 31486.00 & 36969.00 & 36717.00 & 28774.00 & 26896.00 & 29153.00 & 30902.67 \\
\hline & Balance & 29236.83 & 34672.65 & 34426.47 & 26473.27 & 25076.07 & 27290.86 & 29015.12 \\
\hline & \multicolumn{8}{|c|}{ Meat } \\
\hline & Import & 936.88 & 777.90 & 860.88 & 762.13 & 747.27 & 791.30 & 806.16 \\
\hline & Export & 3263.61 & 2875.81 & 2946.45 & 327 & 3720.48 & 3890.91 & 4209.27 \\
\hline & Balance & 2326.73 & 2097.91 & 2085.57 & 2513.62 & 2973.21 & 3099.61 & 3403.11 \\
\hline \multirow{16}{*}{$\frac{. \pi}{2}$} & \multicolumn{8}{|c|}{ Wheat } \\
\hline & Import & 78555.76 & 79592.93 & 90756.50 & 88138.30 & 84639.86 & 85581.60 & 92631.63 \\
\hline & Export & 15203.02 & 16248.82 & 15785.09 & 17392.50 & 17257.52 & 14005.93 & 14552.85 \\
\hline & Balance & -63352.74 & -63344.11 & -74971.41 & -70745.80 & -67382.34 & -71575.67 & -78078.78 \\
\hline & \multicolumn{8}{|c|}{ Soya } \\
\hline & Import & 99761.57 & 106123.92 & 117974.36 & 118952.14 & 109660.45 & 112861.52 & 115410.58 \\
\hline & Export & 757.41 & 499.01 & 671.01 & 650.01 & 503.01 & 461.01 & 470.94 \\
\hline & Balance & -99004.16 & -105624.91 & -117303.35 & -118302.13 & -109157.44 & -112400.51 & -114939.64 \\
\hline & \multicolumn{8}{|c|}{ Sugar } \\
\hline & Import & 29771.08 & 36563.29 & 34431.87 & 34889.62 & 31223.67 & 31807.40 & 34055.63 \\
\hline & Export & 15540.25 & 18404.49 & 16007.75 & 20134.01 & 19470.28 & 17427.56 & 18760.06 \\
\hline & Balance & -14230.83 & -18158.80 & -18424.12 & -14755.61 & -11753.39 & -14379.84 & -15295.57 \\
\hline & \multicolumn{8}{|c|}{ Meat } \\
\hline & Import & 5095.70 & 5019.39 & 5464.14 & 6005.99 & 6476.12 & 6842.46 & 6964.73 \\
\hline & Export & 2485.29 & 2097.38 & 2023.28 & 2082.89 & 1922.51 & 2006.21 & 1998.26 \\
\hline & Balance & -2610.41 & -2922.01 & -3440.86 & -3923.10 & -4553.61 & -4836.25 & -4966.47 \\
\hline
\end{tabular}

Source: calculated and built by the authors based on the OECD (2020).

The following conclusions can be drawn from Table 1. During the analysed period, OECD countries are characterized by a positive balance for all studied goods, except sugar. The situation is similar in South America, where the grain industry is in short supply, while other groups of goods are produced in surplus. As for North America, the balance for wheat and soya was positive during 2014-2020, while the balance for sugar and meat was negative. Europe is characterized by a predominance of exports of wheat, and from 2017 - sugar, while imports of soya and meat are significant during the study period. The data of Table 1 indicate the low export 
orientation of Africa and Asia. First of all, this can be explained by the peculiarities of natural and climatic conditions, which are decisive for the agricultural sector.

Let us analyse the situation on the international market for the main agricultural items, which will allow us assessing the external aspect of the export potential of each region. Fig. 4 shows wheat exports in a generalized form.

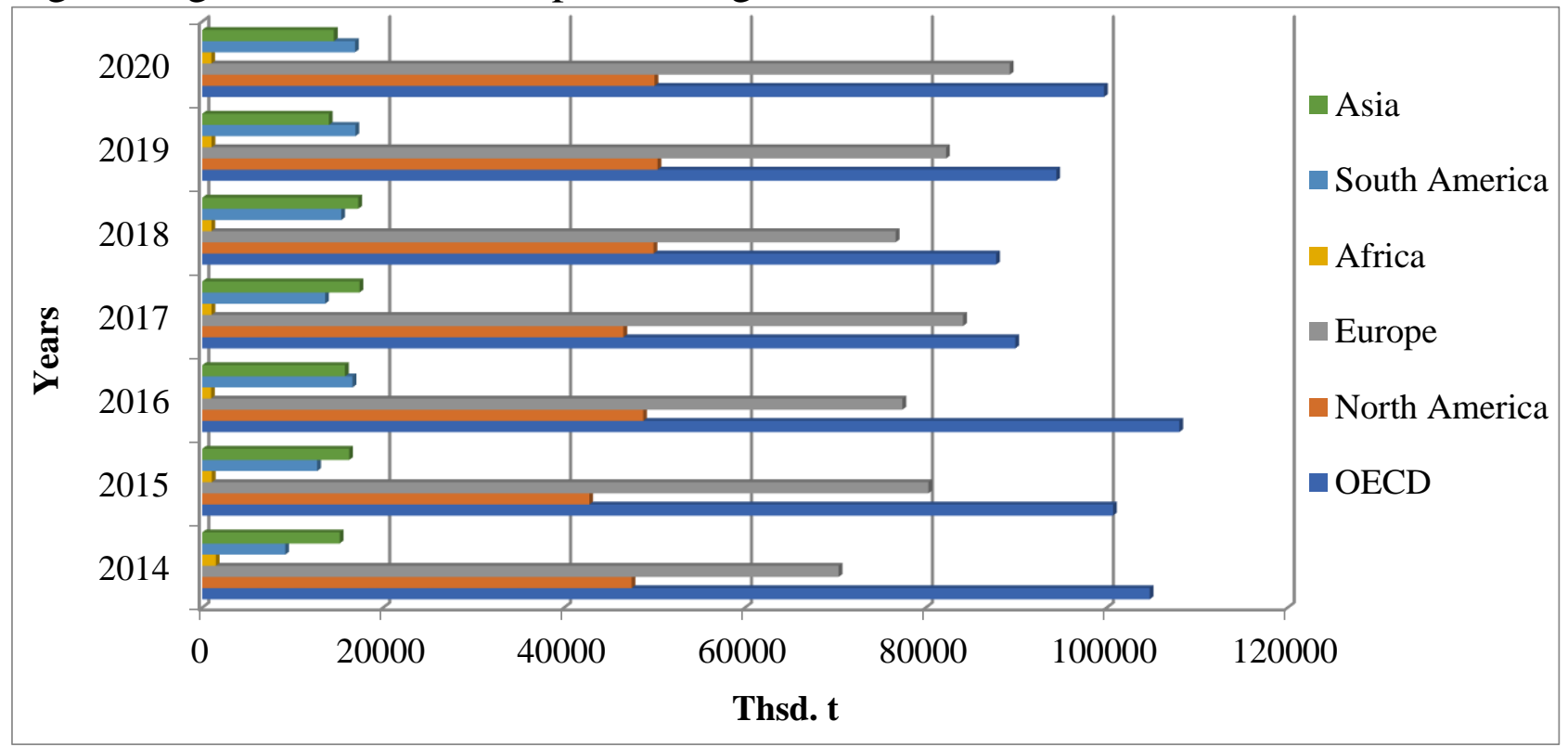

Fig. 4. Wheat exports by regions for 2014-2020, thsd. $t$

Source: calculated and built by the authors based on the OECD (2020).

According to the results, the leaders in the wheat export market are the OECD countries, including Europe and North America. At the same time, the largest volume of exports was in 2016, and the lowest one - in 2018. African countries provide the smallest volume of wheat exports. As for soya exports, Fig. 5 shows that its largest representative on the international market is South America and with a significant gap between OECD countries.

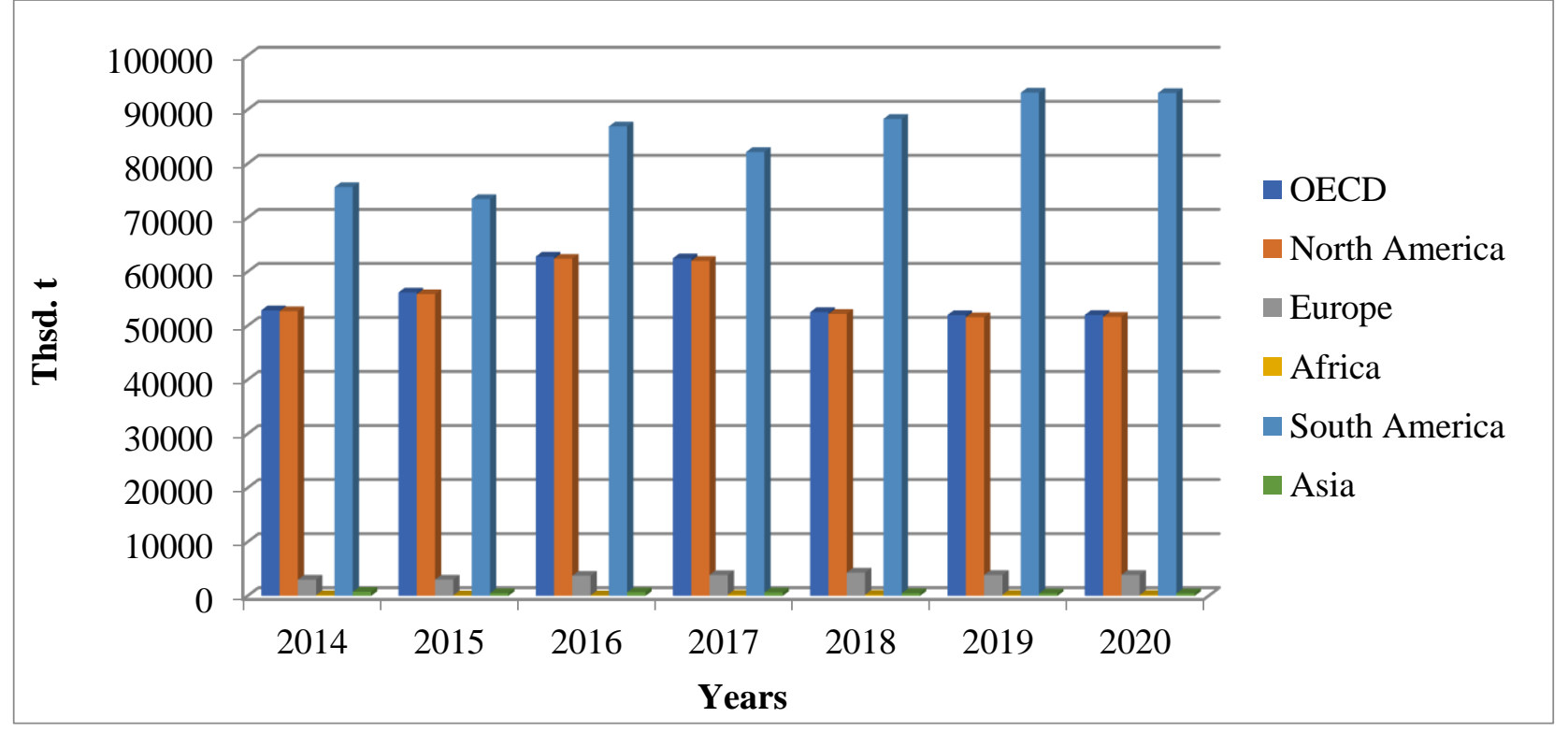

Fig. 5. Soya exports by regions for 2014-2020, thsd. $t$

Source: calculated and built by the authors based on the OECD (2020). 
The peak periods of exports are 2019 and 2020. This trend can be explained by the popularization of soya not only as a food resource, but also its active use as a technical crop for the production of agricultural feed and biofuels. According to Fig. 6, the countries of South America and Asia are the leaders in sugar exports. The largest exports volumes of this product were during 2015-2016, and the lowest ones - at 2018.

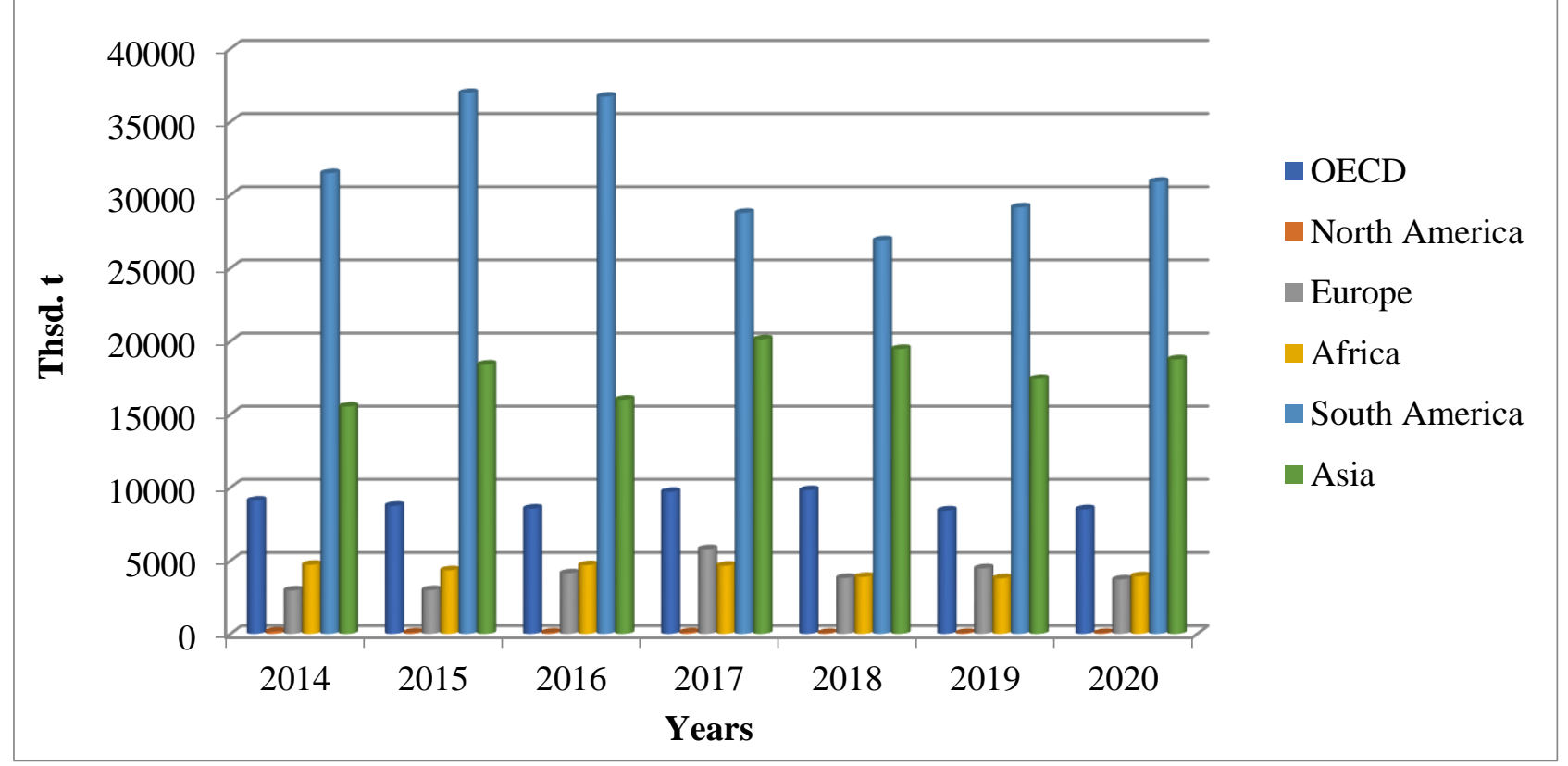

Fig. 6. Sugar exports by regions for 2014-2020, thsd. $t$

Source: calculated and built by the authors based on the OECD (2020).

Analysis of meat exports in 2014-2020 (Fig. 7) indicates that the OECD and South America are dominant in this market.

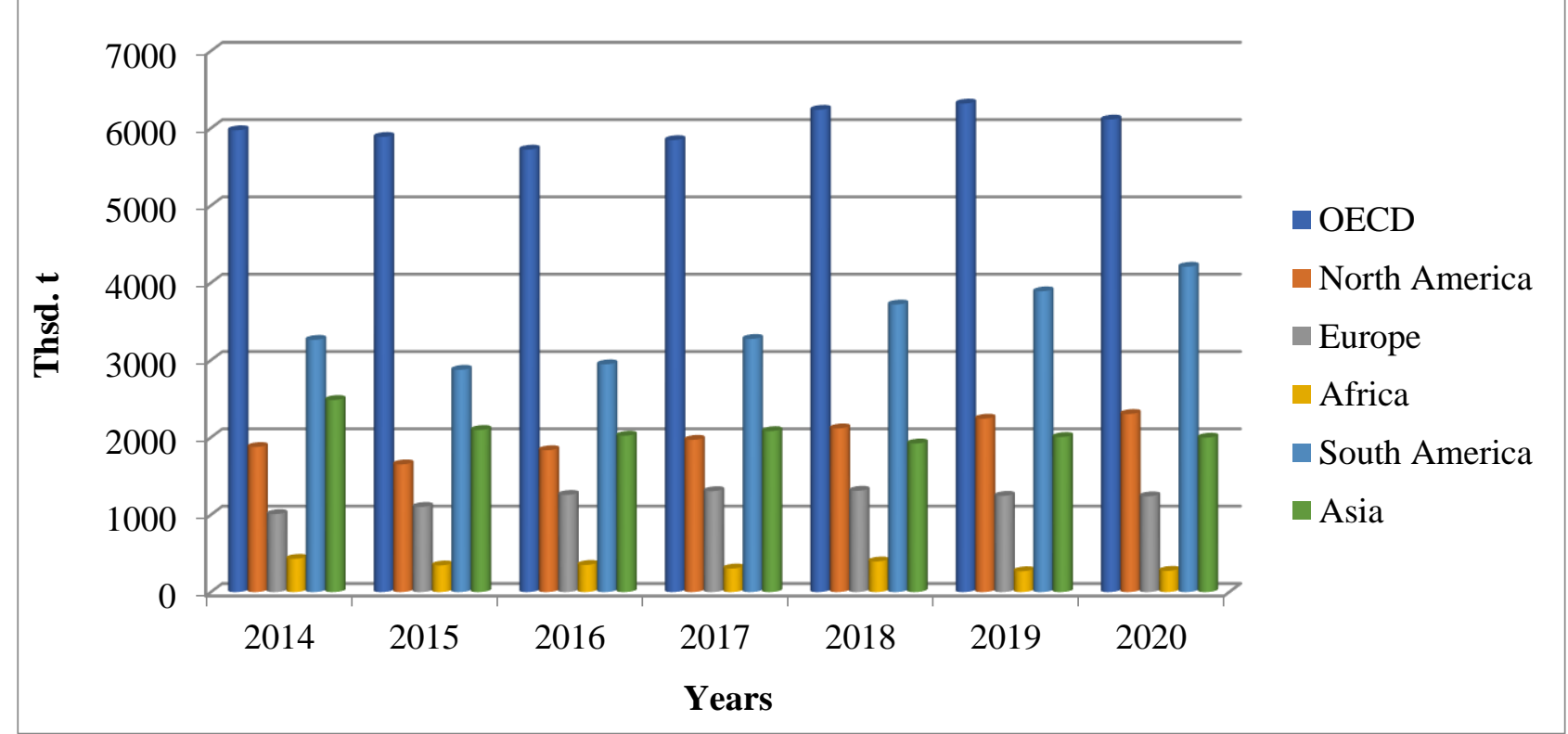

Fig. 7. Meat exports by regions for 2014-2020, thsd. $t$

Source: calculated and built by the authors based on the OECD (2020).

Thus, according to the results of the analysis, it should be concluded that the countries of South America, OECD, North America and Europe have the highest level of export potential. At the same time, African countries are import-dependent for all 
groups of studied agricultural products. In this case, the export potential is represented by the volume of exports, based on the understanding of export potential at the national level. The set of factors that form a competitive advantage in the production of goods act in such a way that domestic production exceeds domestic consumption. As a result, the surplus products is exported. African countries have low export potential, which is reflected in the excess of domestic consumption over domestic production. As a result, the shortage of products is offset by imports.

Analysis of domestic and foreign export potential of each region indicates that the export orientation of industries is largely determined by the favourable natural and climatic conditions for agricultural development, the established traditions of development of such industries and their type of market behaviour. Table 2 presents generalized results of research of internal and external export potential by regions.

Table 2

\section{Domestic and external export potential of agricultural products} in the regional context

\begin{tabular}{|l|l|l|}
\hline \multicolumn{1}{|c|}{ Product type } & \multicolumn{1}{|c|}{$\begin{array}{c}\text { Internal export potential } \\
\text { (positive balance of foreign trade) }\end{array}$} & $\begin{array}{c}\text { External export potential } \\
\text { (the dominant share of exports in the } \\
\text { international market) }\end{array}$ \\
\hline Wheat & $\begin{array}{l}\text { OECD } \\
\text { Europe } \\
\text { North America }\end{array}$ & $\begin{array}{l}\text { OECD } \\
\text { Europe }\end{array}$ \\
\hline Soya & $\begin{array}{l}\text { OECD } \\
\text { South America }\end{array}$ & $\begin{array}{l}\text { North America } \\
\text { South America }\end{array}$ \\
\hline Sugar & Europe & $\begin{array}{l}\text { South America } \\
\text { Asia }\end{array}$ \\
\hline Meat & South America & $\begin{array}{l}\text { OECD } \\
\text { South America }\end{array}$ \\
\hline
\end{tabular}

Source: compiled by the authors based on the results of the study.

Based on the obtained results, it can be concluded that the export potential largely depends on the effectiveness of the development of its domestic component. However, according to Table 2, there is a situation when the region has a negative foreign trade balance, while providing a significant share of exports in the international market - this is a manifestation of the impact of economic activity of the countries in the region and their integration capacity in the context of minimizing the negative impact of the food crisis.

Thus, in order to provide food security, it is advisable to develop measures aimed at agricultural efficiency, expansion and improvement of agro-industrial infrastructure, optimization of investment in export-oriented industries, taking into account domestic and foreign export potential of each country.

Let us analyse the impact of the following indicators on the wheat exports through the regression analysis: the area of sown land, the volume of consumption per capita and the wheat yield. The calculations are based on the example of OECD countries, the leaders in wheat exports on the international market. Table 3 provides initial data for regression analysis. 
Table 3

Initial data for regression analysis of factors influencing the volume of wheat exports on the example of OECD countries

\begin{tabular}{|c|c|c|c|c|}
\hline Years & Export, mln $\mathrm{t}$ & Land area, mln ha & $\begin{array}{c}\text { Consumption per } \\
\text { capita, kg }\end{array}$ & Yield, t per ha \\
\hline 2009 & 87.196 & 74.55672 & 89.02 & 3.48 \\
\hline 2010 & 99.124 & 77.31209 & 89.53 & 3.57 \\
\hline 2011 & 93.373 & 75.64062 & 89.21 & 3.62 \\
\hline 2012 & 94.822 & 74.68890 & 90.69 & 3.54 \\
\hline 2013 & 111.807 & 75.78879 & 90.06 & 3.84 \\
\hline 2014 & 104.899 & 76.81573 & 90.10 & 3.79 \\
\hline 2015 & 100.854 & 76.21027 & 89.89 & 3.89 \\
\hline 2016 & 108.303 & 75.03194 & 90.25 & 3.98 \\
\hline 2017 & 90.138 & 70.17288 & 90.92 & 3.97 \\
\hline 2018 & 88.349 & 70.55418 & 90.29 & 3.74 \\
\hline 2019 & 105.131 & 70.75889 & 89.57 & 4.01 \\
\hline 2020 & 106.204 & 72.28210 & 90.46 & 3.88 \\
\hline
\end{tabular}

Source: compiled by the authors based on the OECD (2020).

The results of the regression analysis are as follows (Tables 4-5).

Table 4

The results of regression analysis of factors influencing the volume of wheat exports

\begin{tabular}{|l|c|c|c|c|}
\hline \multicolumn{1}{|c|}{ Indicator } & Coefficient & Std. Error & t-ratio & p-value \\
\hline Const & -238.8250 & 314.6088 & -0.7591 & 0.4696 \\
\hline Land area, mln ha $\left(\mathrm{x}_{1}\right)$ & 2.2082 & 0.7643 & 2.8890 & $0.0202^{*}$ \\
\hline Consumption per capita, kg $\left(\mathrm{x}_{2}\right)$ & 0.3787 & 3.3609 & 0.1127 & 0.9131 \\
\hline Yield, t per ha $\left(\mathrm{x}_{3}\right)$ & 37.1299 & 10.7369 & 3.4582 & $0.0086^{*}$ \\
\hline
\end{tabular}

Note. *Statistically significant indicator for reliability 0.05 .

Source: built by the authors based on the results of the study.

Table 5

Parameters of statistical reliability of the linear regression equation

\begin{tabular}{|l|c|l|c|}
\hline \multicolumn{1}{|c|}{ Indicator } & \multicolumn{1}{c|}{ Value } & \multicolumn{1}{c|}{ Indicator } & Value \\
\hline $\mathrm{R}$ & 0.8158 & $\mathrm{~F}(3.8)$ & 5.3070 \\
\hline $\mathrm{R}$-squared & 0.6656 & $\mathrm{P}$-value(F) & 0.0263 \\
\hline Durbin-Watson & 1.3615 & Std. Error of estimate & 5.6304 \\
\hline
\end{tabular}

Source: built by the authors based on the results of the study.

So, the theoretical linear regression equation will be as follows:

$$
y=-238.8250+2.2082 x_{1}+0.3787 x_{2}+37.1299 x_{3}
$$

The results of the regression show that the statistically significant factor influencing exports is the size of land on which wheat is grown ( $\mathrm{p}$-value $=0.0202)$ and yield ( $\mathrm{p}$-value $=0.0086$ ). Consumption per capita is not a statistically significant regressor. It is worth noting that the consumption per capita is relatively constant over all periods.

The value of the multiple correlation coefficient indicates that the obtained econometric model adequately describes the studied economic dependence. The 
coefficient of determination $(\mathrm{R}=0.816)$ indicates that about $82 \%$ of the variation in the change in the performance indicator depend on factorial attributes. Regression analysis indicates a direct correlation between the exports volume and the area of land used for wheat cultivation. The constructed one-factor model confirms the positive effect of wheat cultivation area on the volume of its exports in OECD countries (Fig. 8). The pairwise correlation coefficient $(r=0.314)$ in this case indicates the presence of a moderate direct relationship between these indicators. The obtained regression equation $\left(\mathrm{y}=23.203+1.025 \mathrm{x}_{1}\right)$ shows that if the wheat cultivation area increases by $1 \mathrm{mln}$ ha the volume of wheat exports in OECD countries will increase by $1.025 \mathrm{mln}$ t. Thus, the model envisages the need to regulate the self-production of countries in the context of the development of export potential and promote the optimization of the use of natural resources that are strategic for agricultural development.

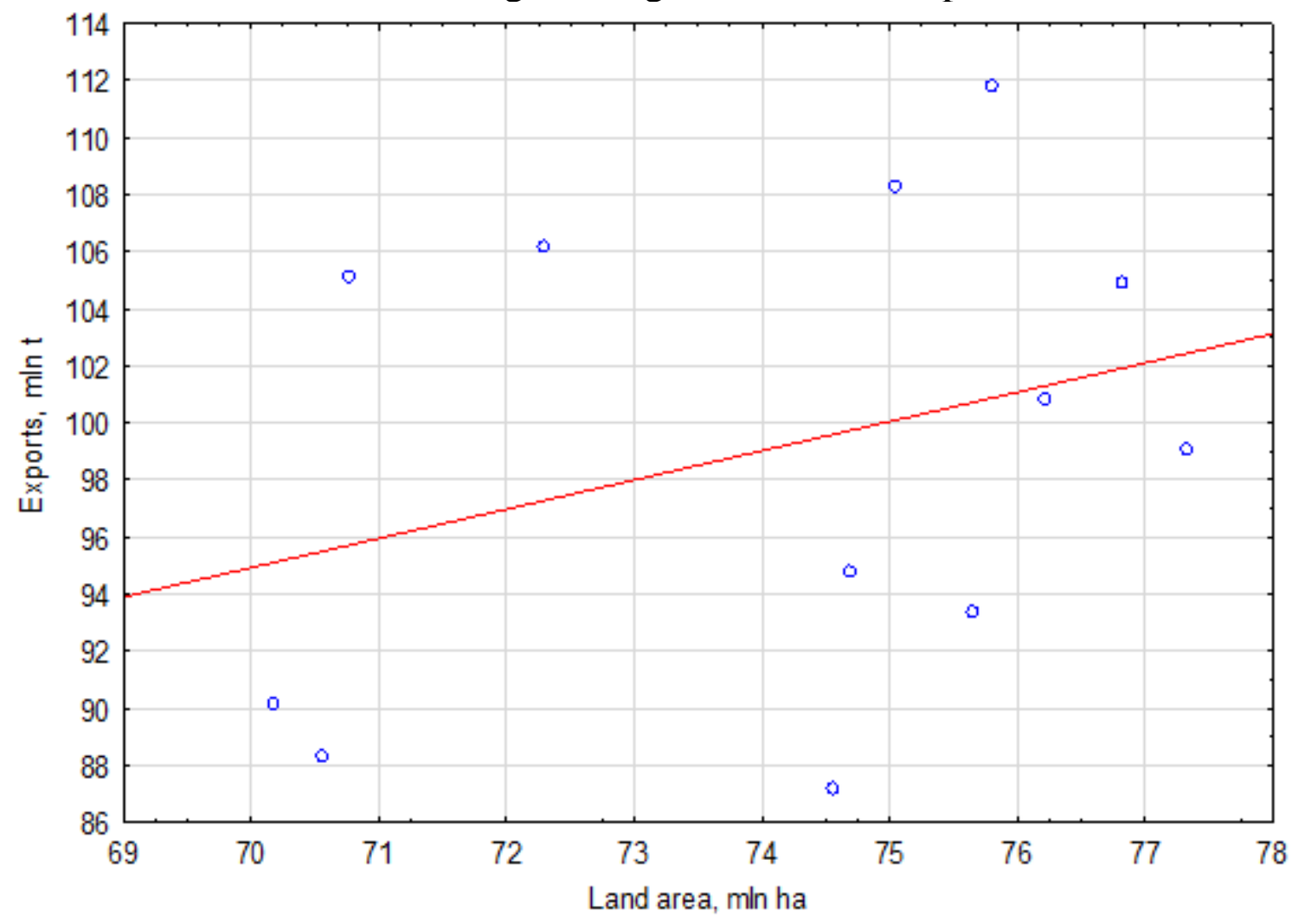

Fig. 8. Impact of wheat cultivation area on the volume of its exports in OECD countries, 2009-2020

Source: built by the authors based on the results of the study.

Our results of the regression analysis of the impact of the sown land area on the wheat exports volume are in line with a similar study conducted by Khan et al. (2020). They confirmed the short-term correlation between sown areas and crop production in terms of agricultural exports and between employment in agriculture and exports of agricultural products.

We agree with Koppenberg et al. (2021), expecting that fulfilling of the export potential of agricultural production during 2020-2021 will significantly transform in the context of the COVID-19 pandemic, in particular due to the impact of export bans imposed by some countries. Thus, the global food system will change significantly due 


\section{Agricultural and Resource Economics: International Scientific E-Journal}

http://are-journal.com

to: reduced access to human resources (reduction of seasonal labour due to travel restrictions; staff morbidity and restrictions in public life); accumulation of stocks of agricultural products due to food insecurity, which is associated with the disruption of supply chains around the world; reducing demand for food due to reduced tourist flows; forced temporary shutdown of the economy, which led to a decrease in economic activity, a sharp rise in unemployment and, consequently, to a decrease in income, which may have an unpredictable impact on demand for agricultural products. Espitia et al. (2020) analyse the impact of Covid-19 on world food markets. The initial shock caused by the pandemic is expected to result in decreased production of labourintensive products due to morbidity and restrictions for workers. Importing countries, which are largely developing and least developed, are projected to suffer the most.

Despite requests from international organizations, governments and trade economists to refrain from imposing trade-distorting measures, more than 20 countries have introduced bans on agricultural and food exports since the beginning of the COVID-19 crisis (Koppenberg et al., 2020). These export bans could adversely affect food security and disrupt established global supply chains.

The first attempt to quantify the effects of the current crisis in food markets was a study by the World Bank (Espitia et al., 2020), which identified the directions of scientific research in this area. First, the Covid-19 industry impact analysis could be supplemented to take into account other factors that differ in the export of certain foods, such as differences in the sensitivity of time or in the production cycle of different crops. Similarly, the impact of supply shocks on prices will be mitigated by factors that vary by sector, such as the availability of buffer stocks. Secondly, the analysis is based on a partial equilibrium model, which does not consider the fact that food demand has also suffered from the crisis. Therefore, it would be appropriate to adjust the results obtained in the study after the end of the pandemic for relevant data and to investigate the intensification of the food crisis in certain countries.

Conclusions. A single economic system is being formed in the context of globalization, which is characterized by asymmetric development of its elements due to the peculiarities and differences between countries in their integration process. The main objective is to ensure the effective functioning of economic systems and minimize the risks, as well as negative trends caused by global transformations. One of those urgent problems is to slow down and prevent the deepening of the global food crisis. It is necessary to study the export potential of agricultural production to ensure its acceptable level in the world. Thus, the processes of globalization and integration, as well as the pandemic intensify competition in the global food market.

Therefore, considering the realization of export potential the countries should identify measures to improve the efficiency of agricultural production, improve its logistics, investment support to increase competitiveness, intensify the sale of agricultural products to foreign economic entities.

The study found that such product groups as wheat and sugar had the greatest export potential during 2014-2020. In general, trade is characterized as follows:

- the OECD countries, South America are characterized by a positive balance for 


\section{Agricultural and Resource Economics: International Scientific E-Journal}

http://are-journal.com

all surveyed goods except sugar. However, the grain industry is in short supply in South America;

- in North America, the balance of wheat and soy was positive, while the balance of sugar and meat was negative;

- Europe is characterized by a predominance of wheat exports, and since 2017 sugar, while imports of soybeans and meat are significant;

- African and Asian countries are characterized by low export orientation due to climatic conditions.

The OECD and European countries are leaders in the wheat export market, while sugar - in South America and Asia, and meat in the OECD and South America. At the same time, African countries are import-dependent for all groups of studied agricultural products.

The impact of domestic and external export potentials was found on the example of wheat exports, according to which there is a direct correlation between the volume of exports and the area of land used for growing wheat, as well as with its yield.

The obtained results can be used to build a strategy of the country export potential, based on the comparative advantages of national economies and the ability to produce the goods in which countries have comparative advantages. The production of products with comparative advantages will allow exporting their surplus to foreign markets, which will increase the export potential of the national economy.

Therefore, a new direction of research may be the implementation of the above strategic areas and their effectiveness not only in agriculture but also in related industries, including engineering, food industry, other sectors of the economy, and the impact of the pandemic on the export potential of agricultural production.

\section{References}

1. Anania, G. (2013), Agricultural export restrictions and the WTO: what options do policy-makers have for promoting food security? Issue paper 50, International Centre for Trade and Sustainable Development (ICTSD), Geneva, Switzerland, available at: https://www.researchgate.net/publication/262560323.

2. Elbushra, A. A., Karim, I. E. A. and Suleiman, I. (2011), The role of COMESA in promoting intra- regional agricultural trade: Case study of Sudan. Journal of the Saudi Society of Agricultural Sciences, vol. 10, is. 2, pp. 59-64. https://doi.org/10.1016/j.jssas.2011.03.004.

3. Espitia, Al., Rocha, N. and Ruta, M. (2020), COVID-19 and food protectionism: the impact of the pandemic and export restrictions on world food markets. Policy Research Working Paper, no. 9253. World Bank, Washington, USA, available at: https://openknowledge.worldbank.org/handle/10986/33800.

4. FAO (2017), The state of food and agriculture leveraging food systems for inclusive rural transformation, available at: http://www.fao.org/3/a-I7658e.pdf.

5. Ferro, E., Otsuki, Ts. and Wilson, J. S. (2015), The effect of product standards on agricultural exports. Food Policy, vol. 50, pp. 68-79. https://doi.org/10.1016/j.foodpol.2014.10.016.

6. Firlej, K. and Kubala, S. (2018), The assessment of export potential of 


\section{Agricultural and Resource Economics: International Scientific E-Journal}

http://are-journal.com

agricultural and food products in the Visegradgroup countries in the years 2005-2017. Economic Sciences for Agribusiness and Rural Economy, vol. 2, pp. 167-173. https://doi.org/10.22630/ESARE.2018.2.21.

7. Ganza, I. V. (2015), Export potential of domestic enterprises of agro-industrial complex in discourse of integration into European market. Global and National Problems of Economy, vol. 5, pp. 116-121, available at: http://globalnational.in.ua/archive/5-2015/24.pdf.

8. Gilbert, C. L. (2012), International agreements to manage food price volatility.
Global
Food
Security,
vol. 1,
is. 2 ,
pp. 134-142. https://doi.org/10.1016/j.gfs.2012.10.001.

9. Headey, D. and Fan, S. (2010), Reflections on the global food crisis. How did it happen? How has it hurt? And how can we prevent the next one? Research reports, no. 165. International Food Policy Research Institute (IFPRI), Washington, D.C., USA, available at: https://ideas.repec.org/p/fpr/resrep/165.html.

10. Hoffmann, U. (2011), Assuring food security in developing countries under the challenges of climate change: key trade and development issues of a fundamental transformation of agriculture. UNCTAD Discussion Paper, no. 201, Geneva, Switzerland, available at: www.unctad.org/en/docs/osgdp20111_en.pdf.

11. Hranovska, V. (2018), Export potential of agrarian enterprises of Ukraine as an indicator of their competitiveness. Agrosvit, vol. 6, pp. 32-39.

12. Huai, D., Maeda, K. and Wang, X. (2020), The impact of country reputation on export quality of agricultural products. Journal of the Faculty of Agriculture, vol. 65, is. 1, pp. 193-199. https://doi.org/10.5109/2558912.

13. Khan, Z. A., Koondhar, M. A., Aziz, N., Ali, U. and Tianjun, L. (2020), Revisiting the effects of relevant factors on Pakistan's agricultural products export. Agricultural Economics - Czech, vol. 66, pp. 527-541. https://doi.org/10.17221/252/2020-AGRICECON.

14. Koppenberg, M., Bozzola, M., Dalhaus, T. and Hirsch, St. (2021), Mapping potential implications of temporary COVID-19 export bans for the food supply inimporting countries using precrisis trade flows. Agribusiness, vol. 37, is. 1, pp. 2543. https://doi.org/10.1002/agr.21684.

15. Lavriv, I. (2016), The factors affecting the export potential and its formation under the conditions of integration. Baltic Journal of Economic Studies, vol. 2, is. 2, pp. 78-84. https://doi.org/10.30525/2256-0742/2016-2-2-78-84.

16. Liefert, W. M. and Westcott, P. C. (2015), Alternative policies to agricultural export taxes that are less market distorting. ERR-187, U.S. Department of Agriculture, Economic Research Service, available at: https://www.ers.usda.gov/webdocs/publications/45373/err-187.pdf?v=1356.2.

17. Maximov, A. and Saha, D. (2017), Unlocking the export potential of Georgian agriculture. Policy Paper Series [PP/01/2017], ISET Policy Institute, German Economic Team Georgia, Berlin-Tbilisi, available at: https://www.get-georgia.de/wpcontent/uploads/2017/04/PP_01_2017_en.pdf.

18. Nakonechna, K. V. (2019), Export potential of agricultural products of 
Ukraine: perspectives of development. Efektyvna ekonomika, vol. 10, https://doi.org/10.32702/2307-2105-2019.10.50.

19. Narayan, S. and Nguyen, T. T. (2016), Does the trade gravity model depend on trading partners? Some evidence from Vietnam and her 54 trading partners. International Review of Economics \& Finance, vol.41, pp. 220-237. https://doi.org/10.1016/j.iref.2015.08.010.

20. OECD (2020), Agriculture and fisheries, available at: http://www.oecd.org/agriculture.

21. Olayiwola, W., Osabuohen, E., Okodua, H. and Ola-David, O. (2015), Economic integration, trade facilitation and agricultural exports performance in ECOWAS sub-region In Regional integration and trade in Africa, eds M. Ncube, I. Faye and A. Verdier-Chouchane, Palgrave Macmillan, New York, USA. https://doi.org/10.1057/9781137462053.0012.

22. Osabohien, R., Akinpelumi, D., Matthew, O. et al. (2019), Agricultural exports and economic growth in Nigeria: an econometric analysis. Proceedings of the IOP Conference Series: Earth and Environmental Science, vol.331, art. no. 012002IOP. https://doi.org/10.1088/1755-1315/331/1/012002.

23. Pang, L. and Wang, Q. (2019), Statistical analysis of the impact of environmental regulation on China's agricultural products export. Proceedings of the IOP Conference Series: Earth and Environmental Science, vol. 252, no. 4, 042125. https://doi.org/10.1088/1755-1315/252/4/042125.

24. Rahman, M. M. and Dutta, D. (2012), The gravity model analysis of Bangladesh's trade: a panel data approach. Journal of Asia-Pacific Business, vol. 13, is. 3, pp. 263-286. https://doi.org/10.1080/10599231.2012.687616.

25. Remeikiene, R., Gaspareniene, L. and Volkov, A. (2018), Evaluation of the influence of the export in agricultural products on the Baltic states economic growth. Montenegrin Journal of Economics, vol. 14, is. 3, pp. 83-94. https://doi.org/10.14254/1800-5845/2018.14-3.6.

26. Richardson, K., Chigozie, N. N. and Chinenye, E. I. (2020), Potential impacts of free trade areas and common currency on sustainable agricultural export in Africa. Journal of Public Affairs, e2392. https://doi.org/10.1002/pa.2392

27. Rossokha, V. and Sharapa, O. (2016), Export potential of agricultural enterprises. Foreign Trade: Economics, Finance, Law, vol. 4, pp. 44-63.

28. Saikevych, M. I. and Saikevych, O. D. (2013), Export potential of agricultural enterprises. Innovative Economy, vol. 3, pp. 104-110.

29. Shobande, O. A. (2019), Effect of trade integration on agricultural export performance in selected west African countries. Economics, vol. 7, is. 3, 79. https://doi.org/10.3390/economies7030079.

30. Shokrollah, H., Moghaddasi, R., Zeraatkish, Y. and Mohammadinejad, A. (2020), An application of stochastic frontier gravity approach (the case of Iran's potential agricultural exports). International Journal of Analysis and Applications, vol. 18, is. 3, pp. 482-492. https://doi.org/10.28924/2291-8639-18-2020-482.

31. Sidorskiy, S. S. ed. (2014), Agroindustrial policy of the Eurasian economic 
union, available

http://www.eurasiancommission.org/ru/Documents/APK_ing_n.pdf.

32. Turobova, H. and Kodirov, Az. (2016), The ways to increase the export potential of the farms. International Journal of Innovative Technologies in Economy, vol. 4 , is. 6 , pp. $27-31$.

Citation:

Стиль-ДСТУ:

Al-Ababneh H. A., Osmonova A., Dumanska I., Matkovskyi P., Kalynovskyy A. Analysis of export of agricultural products in the context of the global food crisis. Agricultural and Resource Economics. 2021. Vol.7. No. 4. Pp. 5-26. https://doi.org/10.51599/are.2021.07.04.01.

Style-APA:

Al-Ababneh, H. A., Osmonova, A., Dumanska, I., Matkovskyi, P. and Kalynovskyy, A. (2021), Analysis of export of agricultural products in the context of the global food crisis. Agricultural and Resource Economics, vol. 7, no. 4, pp. 5-26. https://doi.org/10.51599/are.2021.07.04.01. 